\title{
The Effects of Peripheral and Central High Insulin on Brain Insulin Signaling and Amyloid- $\beta$ in Young and Old APP/PS1 Mice
}

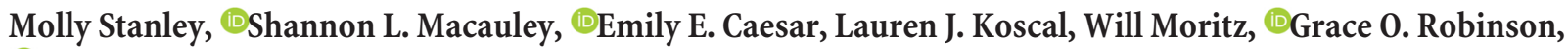 \\ - Joseph Roh, Jennifer Keyser, Hong Jiang, and David M. Holtzman \\ Department of Neurology, Hope Center for Neurological Disorders, Charles F. and Joanne Knight Alzheimer's Disease Research Center, Washington \\ University, St. Louis, Missouri 63110
}

Hyperinsulinemia is a risk factor for late-onset Alzheimer's disease (AD). In vitro experiments describe potential connections between insulin, insulin signaling, and amyloid- $\beta(\mathrm{A} \beta)$, but in vivo experiments are needed to validate these relationships under physiological conditions. First, we performed hyperinsulinemic-euglycemic clamps with concurrent hippocampal microdialysis in young, awake, behaving $A P P_{s w e} / P S 1_{d E g}$ transgenic mice. Both a postprandial and supraphysiological insulin clamp significantly increased interstitial fluid (ISF) and plasma $\mathrm{A} \beta$ compared with controls. We could detect no increase in brain, ISF, or CSF insulin or brain insulin signaling in response to peripheral hyperinsulinemia, despite detecting increased signaling in the muscle. Next, we delivered insulin directly into the hippocampus of young APP/PS1 mice via reverse microdialysis. Brain tissue insulin and insulin signaling was dose-dependently increased, but ISF A $\beta$ was unchanged by central insulin administration. Finally, to determine whether peripheral and central high insulin has differential effects in the presence of significant amyloid pathology, we repeated these experiments in older APP/PS1 mice with significant amyloid plaque burden. Postprandial insulin clamps increased ISF and plasma $A \beta$, whereas direct delivery of insulin to the hippocampus significantly increased tissue insulin and insulin signaling, with no effect on $A \beta$ in old mice. These results suggest that the brain is still responsive to insulin in the presence of amyloid pathology but increased insulin signaling does not acutely modulate $A \beta$ in vivo before or after the onset of amyloid pathology. Peripheral hyperinsulinemia modestly increases ISF and plasma A $\beta$ in young and old mice, independent of neuronal insulin signaling.

Key words: amyloid-beta; APP/PS1; hyperinsulinemic-euglycemic clamps; insulin; insulin receptor signaling; microdialysis

Significance Statement

The transportation of insulin from blood to brain is a saturable process relevant to understanding the link between hyperinsulinemia and AD. In vitro experiments have found direct connections between high insulin and extracellular A $\beta$, but these mechanisms presume that peripheral high insulin elevates brain insulin significantly. We found that physiological hyperinsulinemia in awake, behaving mice does not increase CNS insulin to an appreciable level yet modestly increases extracellular $\mathrm{A} \beta$. We also found that the brain of aged APP/PS1 mice was not insulin resistant, contrary to the current state of the literature. These results further elucidate the relationship between insulin, the brain, and $\mathrm{AD}$ and its conflicting roles as both a risk factor and potential treatment.

\section{Introduction}

Alzheimer's disease (AD), the most common cause of dementia, is characterized by a cascade of pathological events, including the

\footnotetext{
Received July 2, 2016; revised Sept. 13, 2016; accepted Sept. 25, 2016.

Author contributions: M.S., S.L.M., and D.M.H. designed research; M.S., S.L.M., E.E.C., L.J.K., W.M., G.O.R., J.R., J.K., and H.J. performed research; M.S., S.L.M., E.E.C., and D.M.H. analyzed data; M.S. wrote the paper.

This work was supported by National Science Foundation DGE-1143954 to M.S., National Institute on Aging K01 AG050719 to S.L.M., National Institute of Neurological Disorders and Stroke F32 NS080320 to S.L.M., Donors Cure Foundation New Vision Award to S.L.M., and National Institute of Neurological Disorders and Stroke P01 NS080675 to D.M.H. We thank Ron Perez (Hope Center Surgery core at Washington University) for performing dual cannulation surgeries and the Core Laboratory for Clinical Studies at Washington University.
}

formation of extracellular amyloid plaques and intracellular neurofibrillary tangles. The majority of $\mathrm{AD}$ cases $(>99 \%)$ are classified as sporadic or late-onset where age, genetics, environment, and other diseases likely play a role in its development (Holtzman et al., 2011; Musiek and Holtzman, 2015). Type 2 diabetes (T2D) increases the risk of $\mathrm{AD}$ twofold to fourfold (Sims-Robinson et

The authors declare no competing financial interests.

Correspondence should be addressed to Dr. David M. Holtzman, 660 South Euclid, Campus Box 8111, St. Louis, M0 63110.E-mail: holtzman@neuro.wustl.edu.

DOI:10.1523/JNEUROSCI.2119-16.2016

Copyright $\odot 2016$ the authors $\quad 0270-6474 / 16 / 3611704-12 \$ 15.00 / 0$ 
al., 2010) and with approximately one-third of Americans age 65 and older having T2D (www.diabetes.org), a substantial amount of research seeks to understand the connections between T2D and $\mathrm{AD}$. T2D is characterized by hyperinsulinemia, insulin resistance, and hyperglycemia. Longitudinal data suggest that hyperinsulinemia, even without T2D, can double the risk of developing AD (Luchsinger et al., 2004). Cross-sectional studies have also found that hyperinsulinemia is associated with an increased risk of AD (Kuusisto et al., 1997) and the presence of amyloid plaques (Willette et al., 2015). AD patients reportedly have higher blood insulin levels compared with healthy controls (Fujisawa et al., 1991; Craft et al., 1998; Ma et al., 2016). Therefore, high insulin, specifically, may be modulating the risk of $\mathrm{AD}$ in several potential ways (Stanley et al., 2016).

The formation of amyloid plaques begins $\sim 15$ years before the onset of clinical symptoms (Sperling et al., 2011), providing a window for other physiological changes to initiate or influence amyloid deposition. Amyloid plaques are formed by the accumulation and aggregation of extracellular amyloid- $\beta(\mathrm{A} \beta)$, which is released from cells into the interstitial fluid (ISF) (Holtzman et al., 2011; Musiek and Holtzman, 2015). The conversion of monomeric $A \beta$ to toxic species and amyloid plaques is concentration-dependent (Selkoe, 2004; Bero et al., 2011), thus investigating the regulation of extracellular $\mathrm{A} \beta$ levels is crucial in understanding $\mathrm{AD}$ pathogenesis. High insulin promotes amyloid precursor protein (APP) processing to increase extracellular $\mathrm{A} \beta$ through activation of insulin receptor (IR) signaling in vitro (Gasparini et al., 2001; Pandini et al., 2013; Stöhr et al., 2013). In mice, endogenous neuronal IR signaling contributes to higher $A \beta$ levels and amyloid deposition in vivo (Stöhr et al., 2013). Because both insulin and $A \beta$ are degraded by the insulin degrading enzyme (IDE), in vitro experiments show that IDE will preferentially degrade insulin leading to higher levels of extracellular $A \beta$ if insulin levels are high (Qiu et al., 1998). Injection of exogenous $A \beta$ into the rat brain to study $\mathrm{A} \beta$ clearance corroborates that coinjection with insulin significantly reduces A $\beta$ clearance (Shiiki et al., 2004), but this has not been validated under endogenous circumstances.

The majority of brain insulin is made in the periphery and crosses the blood-brain barrier (BBB) through a saturable, receptormediated process (Banks et al., 1997; Banks, 2004). However, there is evidence that insulin may also be produced in the brain (Mehran et al., 2012). Hyperinsulinemic-euglycemic clamps increase plasma and CSF insulin and A $\beta$ levels in humans (Watson et al., 2003; Fishel et al., 2005). Interestingly, this hyperinsulinemia also led to subtle improvements in memory performance. Based on these experiments and the notion that the brain becomes insulin resistant in AD (Craft et al., 1998; Bomfim et al., 2012; Talbot et al., 2012), intranasal insulin is being tested in clinical trials for AD (Wadman, 2012). Although previous experiments have been crucial in understanding the potential interactions between insulin, insulin signaling, and $\mathrm{A} \beta$, in vivo, mechanistic experiments are still needed to determine whether physiological hyperinsulinemia increases brain insulin and positively regulates $A \beta$. It is also unclear whether direct delivery of insulin to the brain, the concept behind intranasal treatment, modulates IR signaling or $A \beta$ in vivo. Here, we determined the effects of peripheral, physiological hyperinsulinemia and CNS delivery of insulin on IR signaling and ISF $A \beta$ in the absence and presence of amyloid pathology to further understand the role of insulin as a risk factor and its effects in the presence of AD pathology.

\section{Materials and Methods}

Animals. Male and female mice heterozygous for the APPswe/PS1 $\triangle E 9$ (APP/PS1) transgene (Borchelt et al., 1997) on a B6C3 background were used. Mice were used at 3 months (young) or 12 months (old) and gender matched for all experiments. Mice were given food and water ad libitum and maintained on a 12:12 light/dark cycle. At the end of each experiment, mice were perfused with ice-cold PBS with $0.3 \%$ heparin. All protocols were approved by the Animal Studies Committee at Washington University.

Hyperinsulinemic-euglycemic clamps with microdialysis. Three-month or 12-month-old APP/PS1 mice ( $n=7$ per group) underwent catheterization of the jugular vein and femoral artery $5 \mathrm{~d}$ before the clamps as described previously (Macauley et al., 2015). Guide cannulas (BR-style Bioanalytical Systems) were implanted into the left hippocampus (from bregma anteroposterio $-3.1 \mathrm{~mm}$, mediolateral $-2.5 \mathrm{~mm}$, dorsoventral $-1.2 \mathrm{~mm}$ at $12^{\circ}$ angle) and secured with dental cement $2 \mathrm{~d}$ before clamps, and mice were transferred to Raturn sampling cages (Bioanalytical Systems). The left hemisphere was collected after perfusion, and cresyl violet staining was used to confirm probe placement. One day before clamps, microdialysis probes $(2 \mathrm{~mm} ; 38 \mathrm{kDa}$ molecular weight cutoff, BR-style, Bioanalytical Systems) were inserted into the guide cannula and connected to a syringe pump infusing aCSF at $1 \mu \mathrm{l} / \mathrm{min}\left(1.3 \mathrm{mM} \mathrm{CaCl}_{2}, 1.2\right.$ mм $\mathrm{MgSO}_{4} 3 \mathrm{~mm} \mathrm{KCl}, 0.4$ mм KH2PO $, 25 \mathrm{~mm} \mathrm{NaHCO} 3,122 \mathrm{~mm} \mathrm{NaCl}$, $0.15 \% \mathrm{BSA}, \mathrm{pH} 7.35)$. At the same time, femoral and jugular catheters were externalized and flushed. The jugular line was connected to a Y-connector (Instech Laboratories) and two syringe pumps infusing $0.9 \% \mathrm{NaCl}$ at $1 \mu \mathrm{l} / \mathrm{min}$. The arterial line was also connected to a syringe pump infusing $\mathrm{NaCl}$ at $1 \mu \mathrm{l} / \mathrm{min}$ overnight to keep the lines clear. Hourly collection of hippocampal ISF began at this time. The next morning, mice were fasted $4-5 \mathrm{~h}$ before and during the clamps. Right before the clamp, a blood sample was collected into serum separating tubes (BD Microtainer), briefly centrifuged at $4^{\circ}$ and serum collected and stored at -80 until use. During hyperinsulinemic-euglycemic clamps, one of the Y-connected jugular lines was infused with insulin (Humulin-R, Lilly) in $0.1 \% \mathrm{BSA}-\mathrm{PBS}$ at a constant rate $(1.6 \mu \mathrm{l} / \mathrm{min})$. Insulin was prepared according to body weight to delivery either $4 \mathrm{mU} / \mathrm{kg} / \mathrm{min}$ or $20 \mathrm{mU} / \mathrm{kg} /$ $\mathrm{min}$. Controls received $0.1 \% \mathrm{BSA}-\mathrm{PBS}$ alone at the same rate. The second Y-connected jugular line was infused with $20 \%$ dextrose in PBS in those that received insulin or PBS alone in controls. Every $10 \mathrm{~min}$, blood was sampled via the femoral artery and blood glucose measured by a handheld glucometer (Coutour, Bayer). The glucose infusion rate was adjusted to clamp blood glucose at fasting, euglycemic levels (120-140 $\mathrm{mg} / \mathrm{dl}$ in young, $90-110 \mathrm{mg} / \mathrm{dl}$ in old). A second blood sample was collected at $3 \mathrm{~h}$. At the end of the $4 \mathrm{~h}$ clamp, insulin infusion was stopped, food was returned, and glucose infusion was titrated down until mice maintained euglycemia without infusion $(\sim 30 \mathrm{~min})$. Hourly ISF collection continued throughout the clamp and for $12 \mathrm{~h}$ after clamp. ISF $\mathrm{A} \beta_{1-\mathrm{X}}$, glucose, and lactate were measured immediately at the end of the experiment.

Another set of 3-month-old APP/PS1 mice ( $n=4-8$ per group) were subjected to the same experiment (hyperinsulinemic-euglycemic clamp + hippocampal microdialysis) but ISF collected in $30 \mathrm{~min}$ fractions to measure ISF insulin. Mice were killed after $1.5 \mathrm{~h}$ of clamp to collect CSF. Additional 3-month-old ( $n=6$ per group) and 12-monthold ( $n=7-9$ per group) APP/PS1 mice underwent the hyperinsulinemicclamp procedure described above, without microdialysis, and killed after $1-1.5 \mathrm{~h}$ of clamp to collect CSF and tissue to measure insulin signaling. Blood samples were taken before the start of the clamp and after $1 \mathrm{~h}$ of clamp as described above. ISF, CSF, and tissue were frozen on dry ice immediately and stored at $-80^{\circ}$ until use.

Direct delivery of insulin via reverse microdialysis. Guide cannula implantation and hippocampal microdialysis was performed as described above. Insulin (Humulin-R, Lilly) was infused directly into the hippocampus in aCSF for $1 \mathrm{~h}$ at 40 or $400 \mathrm{~nm}$ after $8 \mathrm{~h}$ of baseline ISF collection in 3-month-old (12-20 per group) and 12-month-old (9-12 per group) APP/PS1 mice and 12-month-old wild-type mice $(n=4$ per group). Controls received regular aCSF. Mice were immediately killed after $1 \mathrm{~h}$ of treatment and the left hippocampus around the probe and right hippocampus without a probe collected for analysis of insulin and insulin signaling. ISF $A \beta_{1-\mathrm{X}}$, glucose, and lactate were measured immediately at the end of the experiment for $9 \mathrm{~h}$ of samples.

Insulin signaling ELISAs. Frozen brain tissue (hippocampus or hypothalamus) and leg muscle collected at $1 \mathrm{~h}$ into hyperinsulinemic- 
euglycemic clamps in 3-month-old ( $n=6$ per group) and 12-month-old APP/PS1 mice ( $n=7-9$ per group) and left and right hippocampi collected after $1 \mathrm{~h}$ of insulin treatment via reverse microdialysis in 3-monthold ( $n=7-12$ per group) and 12-month-old ( $n=7$ per group) APP/PS1 and 12-month-old WT ( $n=4$ per group) mice were analyzed for insulin signaling. Tissue was hand homogenized in $10 \times \mathrm{w} / \mathrm{v}$ RIPA buffer with protease and phosphatase inhibitors (Roche). Homogenates were centrifuged at 14,000 rpm for $30 \mathrm{~min}$ at $4^{\circ}$. Supernatant was collected and used as tissue lysate. Total protein concentration in lysates was determined by Micro BCA (Thermo Scientific) according to the manufacturer's instructions. Phospho-AKT (Ser473)/pan-AKT was measured by ELISA (Sigma-Aldrich: catalog \#RAB0012) according to the manufacturer's instructions. Phospho and total AKT was measured in the same samples on the same plate and the ratio of phospho:total determined for each sample. Phospho-IR (Tyr1158)/pan-IR $\beta$ was measured by ELISA (Invitrogen: catalog \#KHR9121; KHR9111) according to the manufacturer's instructions. All data were normalized to controls, except for direct delivery of insulin via reverse microdialysis where data were normalized to the right hippocampus without a microdialysis probe.

Western blots. Phospho:total AKT was measured to confirm that the ELISA described above accurately represented the same change as a Western blot, the conventional method of measuring p-AKT. Hippocampal lysates (50 $\mu \mathrm{g}$ protein) described above were boiled in LDS sample buffer, run on a $4 \%-12 \%$ Bis-Tris gel, and transferred to $0.2 \mu \mathrm{M}$ nitrocellulose membrane. The membrane was cut at $50 \mathrm{kDa}$ and the bottom halfblocked and incubated in primary GAPDH:HRP antibody (Abcam \#9484). The top half was blocked and incubated in primary $\mathrm{P}$ (Ser473)-AKT antibody (Cell Signaling Technology \#9271) followed by anti-rabbit secondary (Jackson ImmunoResearch Laboratories \#211-032-171), and both halves were visualized with Lumagen ECL and imaged with GeneSnap. The top half was stripped (10\% SDS, 7\% 2-mercaptoethanol, PBS) and reprobed with primary AKT antibody (Cell Signaling Technology \#9272), secondary anti-rabbit, and visualized using ECL and Genesnap. OD of the bands was measured with ImageJ.

Insulin and C-peptide measurements. Serum insulin and C-peptide were measured by ELISA (Alpco: catalog \#80-INSMSU-E01; 80-CPTMSE01) according to the manufacturer's instructions. ISF, CSF, and tissue insulin levels were undetectable by commercial ELISA. Therefore, ISF, CSF, and tissue lysates described above were sent to the Core Laboratory for Clinical Studies at Washington University in St. Louis. This facility used a Singulex Erenna Immunoassay System to measure insulin with better sensitivity $(>10 \mathrm{pg} / \mathrm{ml})$. Some tissue lysate samples were still below the level of detection and those are plotted as $10 \mathrm{pg} / \mathrm{ml}$ for comparison.

IDE activity measurements. IDE activity was measured in brain tissue from 3-month-old APP/PS1 mice that underwent hyperinsulinemiceuglycemic or PBS clamps ( $n=4-7$ per group) for $1 \mathrm{~h}$ using the SensoLyte IDE Activity Assay Kit (AnaSpec: catalog \#AS-72231) according to the manufacturer's instructions. Frozen cortex was hand homogenized $5 \times \mathrm{w} / \mathrm{v}$ in assay buffer, centrifuged, and the supernatant used as lysate. Fluorescence was measured every $10 \mathrm{~min}$ for $90 \mathrm{~min}$, and there was no difference in kinetics between groups. The relative fluorescence at $90 \mathrm{~min}$ per milligrams of protein (determined by MicroBCA) was plotted relative to PBS controls.

Glucose and lactate measurements. ISF glucose and lactate and serum lactate were measured with the YSI 2900 analyzer (YSI) according to the manufacturer's instructions.

$A \beta_{1-X}$ ELISA. ISF and plasma $A \beta 1-\mathrm{x}$ were measured by in-house ELISA described previously (Macauley et al., 2015). Briefly, plates were coated with a monoclonal capture antibody targeted against A $\beta 13-28$ (m266) and detected with biotinylated antibody against A $\beta 1-5$ (3D6). These antibodies were generously provided by Eli Lilly. After incubating in Streptavidin-poly-HRP-20, the assay was developed using Super Slow TMB (Sigma) and read at $650 \mathrm{~nm}$.

Quantification of $A \beta$ deposition. Brains of 3- and 12-month-old APP/ PS1 mice ( $n=5$ per group) were used to quantify the amount of $A \beta$ deposition as described previously (Macauley et al., 2015). Briefly, brains were sliced into $50 \mu \mathrm{m}$ sections on a freezing microtome. Serial sections from anterior to posterior hippocampus were immunostained using biotintylated, HJ3.4 antibody (anti-A $\beta 1-13$, mouse monoclonal antibody) (Macauley et al., 2015) and developed using a Vectastain ABC kit and
$\mathrm{DAB}$ reaction. The brain sections were imaged using a NanoZoomer slide scanner (Hamamatsu Photonics) and the percentage area occupied by A $\beta$ staining was quantified by a blinded researcher. Three-month-old mice had no $\mathrm{A} \beta$ staining as expected; therefore, statistical tests could not be performed.

Data analysis. All data are represented by mean \pm SEM. Statistical significance was determined by two-tailed, unpaired $t$ test (comparing two groups), one-way ANOVA with Dunnett's post test (comparing 3 groups, treatment vs control), or two-way ANOVA with Bonferroni post test (comparing 3 groups, baseline vs treatment for each group). Significant outliers, determined by Grubbs' test $(p<0.05)$ were excluded. Statistical evaluation was performed using Graphpad Prism 5.

\section{Results}

\section{Hyperinsulinemic-euglycemic clamps increase serum insulin without altering glucose or lactate levels in young APP/PS1} mice

To determine how peripheral hyperinsulinemia, at physiological levels, dynamically affects the CNS in awake animals, we performed hyperinsulinemic-euglycemic clamps (Ayala et al., 2006) combined with in vivo microdialysis (Cirrito et al., 2003; Macauley et al., 2015). The clamps allow us to specifically modulate blood insulin levels in awake, behaving mice while using microdialysis to continuously collect ISF from the hippocampus. In 3-month-old $A P P / P S 1$ mice before $\mathrm{A} \beta$ deposition, we clamped insulin at a postprandial level $(4 \mathrm{mU} / \mathrm{kg} / \mathrm{min}, \sim 4$-fold increase in serum insulin) or supraphysiological level $(20 \mathrm{mU} / \mathrm{kg} / \mathrm{min}, \sim 16$ fold increase in serum insulin) for comparison (Fig. 1A). PBS controls underwent the same clamp procedures but received vehicle infusions instead of insulin and glucose. There was a significant increase in serum insulin levels with $4 \mathrm{mU}(p<0.05$, $t=2.6)$ and $20 \mathrm{mU}(p<0.001, t=16.0)$, but insulin levels in PBS controls were unchanged. Because exogenous insulin was infused in the 4 and $20 \mathrm{mU}$ groups, endogenous insulin release should be reduced in response. Therefore, serum C-peptide, which is coreleased from pancreatic $\beta$-cells with insulin, can be used as a proxy of insulin production. Serum C-peptide was reduced with hyperinsulinemic-euglycemic clamps $\sim 2.5$-fold in the $4 \mathrm{mU}$ group $(p<0.01, t=3.7)$ and $\sim 4.5$-fold in the $20 \mathrm{mU}$ group $(p<$ $0.05, t=3.1$ ) (Fig. $1 B$ ). This suggests that endogenous insulin release is reduced as expected. Because euglycemia was maintained in response to insulin by infusing dextrose at variable rates to maintain blood glucose levels at $120-140 \mathrm{mg} / \mathrm{dl}$, there were no differences in blood glucose during the clamps (Fig. 1C). ISF glucose mirrors blood glucose levels due to facilitated diffusion across the BBB (Macauley et al., 2015); therefore, no change in hippocampal ISF glucose was observed during the clamps (Fig. $1 D)$. The glucose infusion rate indicates how much glucose is necessary to maintain euglycemia and is a metric of insulin responsiveness. As expected, more glucose was necessary to maintain euglycemia at the supraphysiological level of insulin $(p<$ $0.05, t=2.7: 52.9 \pm 7.6$ vs $80.8 \pm 6.9 \mathrm{mg} / \mathrm{kg} / \mathrm{min}$ ) (Fig. $1 E)$. We previously found that hyperglycemic clamps increased ISF lactate, which can be used as a marker of neuronal activity (Bero et al., 2011; Macauley et al., 2015); however, no change in ISF lactate in response to hyperinsulinemia was observed (Fig. $1 F$ ). Hyperinsulinemic-euglycemic clamps increase blood lactate in humans (Berhane et al., 2015), but no significant differences in serum lactate levels were found in response to these clamps in young APP/PS1 mice (Fig. $1 G$ ). We successfully increased serum insulin to specific levels in awake, behaving mice using hyperinsulinemic-euglycemic clamps. Although we suppressed endogenous insulin release, we did not affect blood or brain glu- 
A

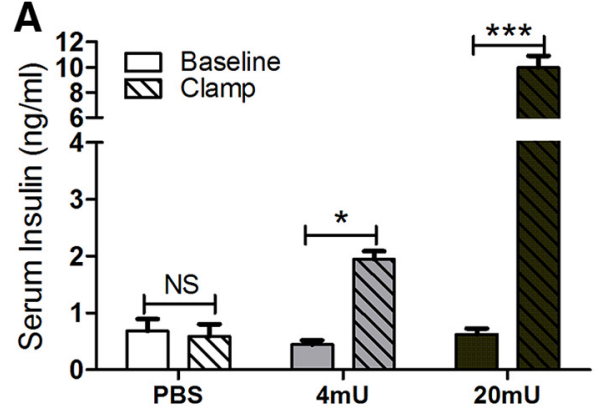

C

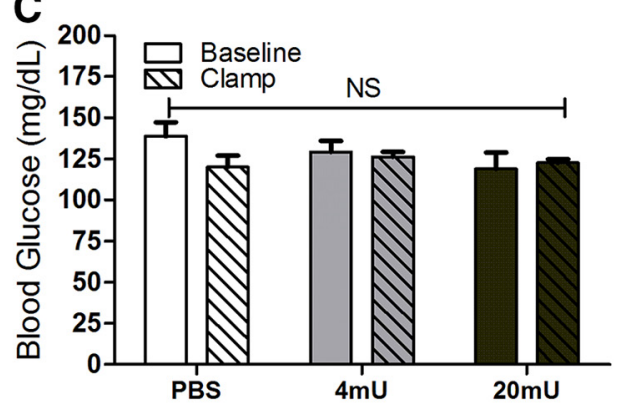

B

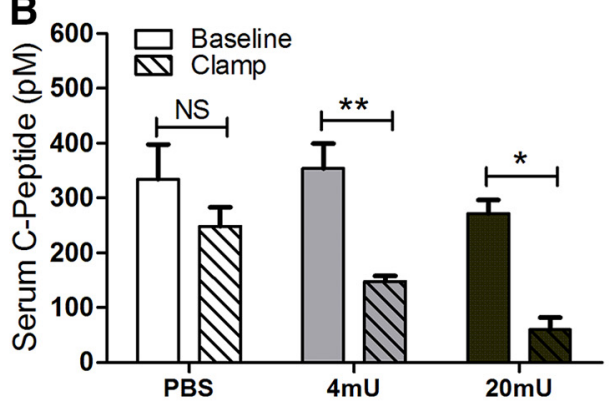

D

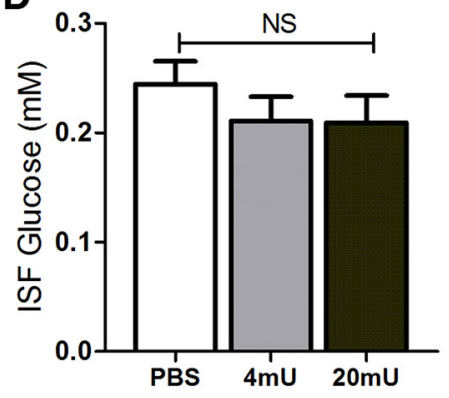

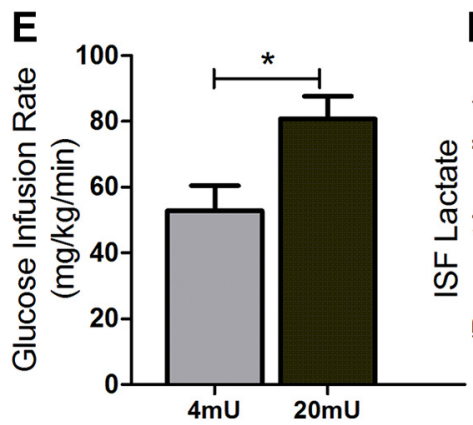

$\mathbf{F}$

G

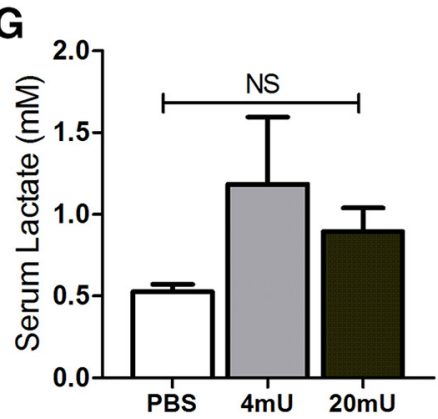

Figure 1. Hyperinsulinemic-euglycemic clamps increase serum insulin without altering glucose or lactate levels in young APP/PS1 mice. A, Serum insulin levels at fasted baseline (solid) and during hyperinsulinemic-euglycemic or PBS clamps (striped) ( $n=7$ per group). B, Serum C-peptide levels at fasted baseline and during the clamps ( $n=5$ or 6 per group). C, Blood glucose levels at fasted baseline and average during the clamps: blood glucose was clamped between 120 and $140 \mathrm{mg} / \mathrm{dl}$ at euglycemic levels throughout the clamps to ensure that there were no changes between baseline and clamp in any condition ( $n=7$ per group). $\boldsymbol{D}$, ISF glucose levels during the clamps ( $n=5-7$ per group). $\boldsymbol{E}$, Average glucose infusion rate throughout hyperinsulinemic-euglycemic clamps, representing the amount of glucose necessary to maintain euglycemia ( $n=7$ per group). $\boldsymbol{F}$, ISF lactate during the clamps as a percentage of $8 \mathrm{~h}$ of baseline ( $n=5-7$ per group). $\boldsymbol{G}$, Serum lactate levels during the clamps ( $n=5$ or 6 per group). Data are mean \pm SEM. NS, not significant. ${ }^{*} p<0.05,{ }^{* *} p<0.01,{ }^{* * *} p<0.001$ (two-way ANOVA with Bonferroni post test, $A-C$; one-way ANOVA with Dunnett's post test, $\mathbf{D}, \boldsymbol{F}, \boldsymbol{G}$; or unpaired, two-tailed $t$ test, $\boldsymbol{E}$ ).

cose or lactate levels, which are known to independently modulate $\mathrm{A} \beta$.

Hyperinsulinemic-euglycemic clamps do not increase CNS insulin or insulin signaling but increase ISF and plasma $A \beta$ in young APP/PS1 mice

To determine whether elevated blood insulin in awake, behaving mice affects CNS insulin levels, we measured hippocampal ISF insulin during hyperinsulinemic-euglycemic or PBS clamps in 3 -month-old APP/PS1 mice. No changes in ISF insulin were detected in response to peripheral hyperinsulinemia (Fig. 2A). Similar to ISF insulin, no significant increase in CSF insulin was detected at 4 or $20 \mathrm{mU}$ compared with PBS controls (Fig. 2B). Others have reported that hyperinsulinemic-euglycemic clamps modestly increase CSF insulin in humans, dogs, and rats (Stein et al., 1987; Baura et al., 1993; Fishel et al., 2005), but this phenomenon has not been reported in mice. In addition, we attempted to measure tissue levels of insulin from the cortex of these mice, but only three samples tested had detectable levels of insulin $(>10$ $\mathrm{pg} / \mathrm{ml}$ ) and they were in both the PBS and insulin groups (data not shown). One potential explanation for why higher insulin levels were not detected in the ISF, CSF, or tissue could be that high insulin may increase IDE levels (Zhao et al., 2004; Pandini et al., 2013), thus increasing insulin degradation. IDE activity was measured in brain tissue collected immediately after $1-1.5 \mathrm{~h}$ of hyperinsulinemic-euglycemic or PBS clamps, but there was no change in IDE activity (Fig. 2C). Because of the nature of the receptor tyrosine kinase-mediated signaling cascade associated with the IR, it is possible that insulin levels do not mirror changes in insulin signaling due to signal amplification and widespread downstream effects (Plum et al., 2005). To measure changes in insulin signaling in response to hyperinsulinemic-euglycemic clamps, brain regions and muscle tissue were collected immediately after $1-1.5 \mathrm{~h}$ of hyperinsulinemia. The muscle, which is exposed to peripheral hyperinsulinemia in the $4 \mathrm{mU}$ group, had significantly increased phospho:total AKT (p-ser473), a major hub in the IR signaling cascade, compared with PBS controls $(p<0.01, t=3.6: 1.0$ vs 1.5) (Fig. $2 D)$. Conversely, no changes in phospho:total AKT in the hippocampus or hypothalamus were detectable following the insulin challenge (Fig. 2E,F). The same 
A

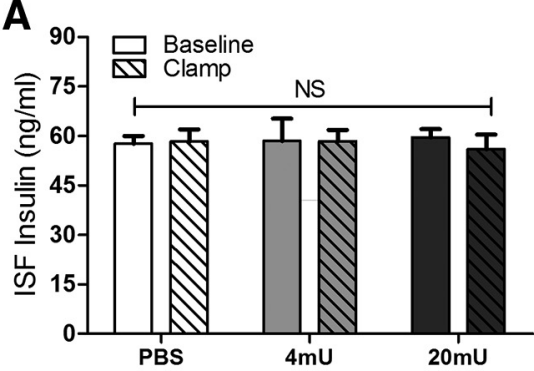

B
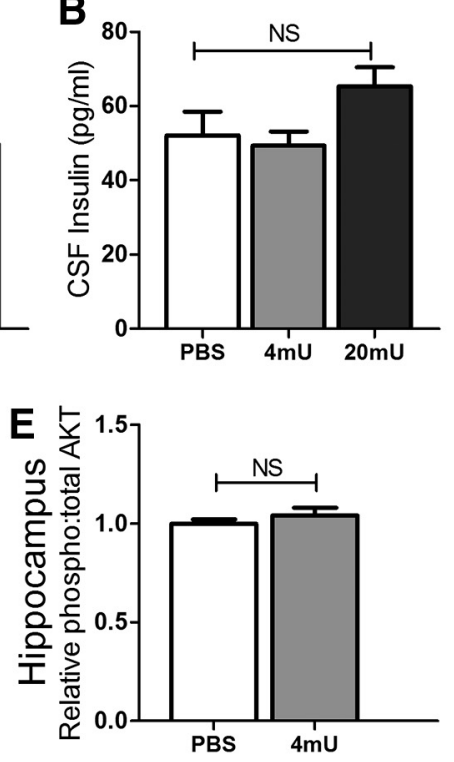
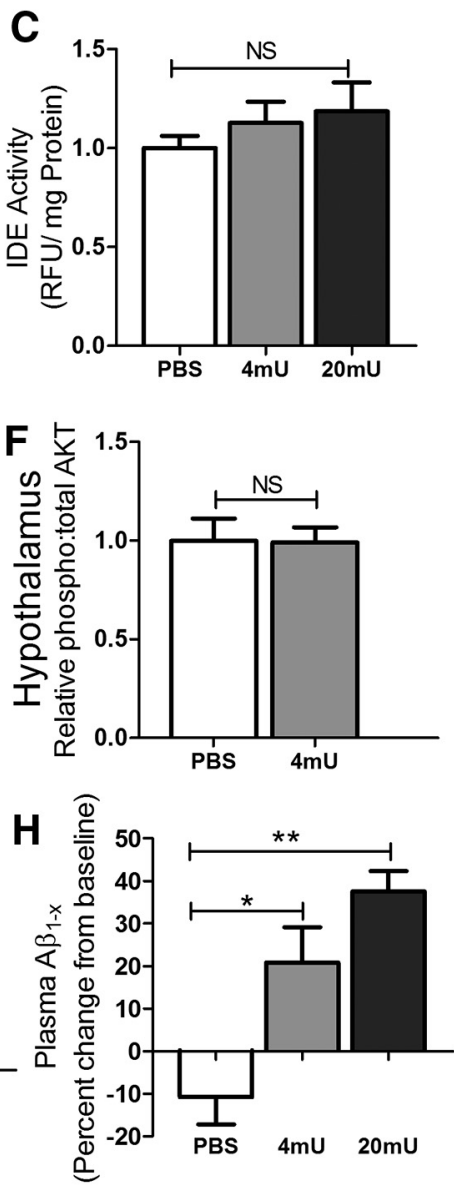

Figure 2. Hyperinsulinemic-euglycemic clamps do not increase CNS insulin or insulin signaling but increase ISF and plasma A $\beta$ in young $A P P / P S 1$ mice. $A$, ISF insulin levels at fasted baseline and average during hyperinsulinemic-euglycemic or PBS clamps ( $n=4-8$ per group). $\boldsymbol{B}$, CSF insulin in samples collected immediately after 1-1.5 h of clamp ( $n=7-10$ per group). C, IDE activity, normalized to total protein per sample, in cortex collected immediately after $1-1.5 \mathrm{~h}$ of clamp ( $n=4-7$ per group). $\boldsymbol{D}-\boldsymbol{F}$, Phospho(ser473):total AKT in leg muscle, hippocampus, and hypothalamus collected after $1 \mathrm{~h}$ of $4 \mathrm{mU}$ or PBS clamp. Normalized to PBS controls ( $n=6$ per group). $\mathbf{G}$, Hourly ISF A $\beta_{1-\mathrm{x}}$ measurements during $8 \mathrm{~h}$ of baseline, $4 \mathrm{~h}$ of clamp, and $13 \mathrm{~h}$ after clamp plotted as percentage change from baseline. Open circles represent PBS. Gray squares represent $4 \mathrm{mU}$. Dark gray diamonds represent $20 \mathrm{mU}$. Average ISF $A \beta_{1-\mathrm{X}}$ during the $4 \mathrm{~h}$ clamp was used to compare the effect of hyperinsulinemia on ISF $A \beta_{1-x}$ compared with PBS controls ( $n=7$ per group). $\boldsymbol{H}$, Plasma $A \beta_{1-x}$ plotted as percentage change from baseline. Baseline samples were collected after fasting and clamp samples collected $1 \mathrm{~h}$ into clamp ( $n=3-6$ per group). Data are mean \pm SEM. NS, not significant. ${ }^{*} p<0.05$, ${ }^{* *} p<0.01$ (two-way ANOVA with Bonferroni post test, $\boldsymbol{A}$; one-way ANOVA with Dunnett's post test, $\boldsymbol{B}, \boldsymbol{C}, \mathbf{G}, \boldsymbol{H}$; or unpaired, two-tailed $t$ test, $\boldsymbol{D}-\boldsymbol{F})$.

trend was seen with phospho:total IR whereby the muscle was increased at $4 \mathrm{mU}$ but the hippocampus was unchanged (data not shown). Therefore, physiological hyperinsulinemia in awake, behaving mice did not increase detectable CNS insulin or insulin signaling.

To explore whether hyperinsulinemia could affect ISF A $\beta$ without affecting insulin signaling, we measured hourly fractions of hippocampal ISF A $\beta$ in 3-month-old APP/PS1 mice during baseline, hyperinsulinemic-euglycemic or PBS clamps, and after clamp. Surprisingly, we found a modest increase in ISF A $\beta$ in response to hyperinsulinemia (Fig. 2G). Averaging over the $4 \mathrm{~h}$ clamp for each animal, there was a significant increase in the 4 $\mathrm{mU}(9.1 \pm 1.7 \%: p<0.05, \mathrm{q}=2.6)$ and $20 \mathrm{mU}(9.9 \pm 4 \%: p<$ $0.05, \mathrm{q}=2.8)$ groups compared with PBS controls $(-0.7 \pm$ $1.6 \%)$. Interestingly, the effect of hyperinsulinemia on ISF A $\beta$ was not dose-dependent, as both postprandial and supraphysiological insulin levels increased $A \beta$ to the same degree. The increase in ISF A $\beta$ was not sustained after clamp in either insulin group. In addition, we found that hyperinsulinemia increased plasma $\mathrm{A} \beta$ in the $4 \mathrm{mU}(20.5 \pm 8.3 \%: p<0.05, \mathrm{q}=3.3)$ and 20 $\mathrm{mU}(37.5 \pm 4.9 \%: p<0.01, \mathrm{q}=4.3)$ clamp groups compared with PBS controls $(-10.8 \pm 6.4 \%)$ as a percentage change from baseline for each animal (Fig. $2 H$ ). These findings demonstrate that acute hyperinsulinemia increases both plasma and ISF A $\beta$, whereas brain insulin levels and insulin signaling remain unaffected. This suggests the possibility that high blood insulin acts peripherally to increase $\mathrm{A} \beta$ levels or influences the net transport of $\mathrm{A} \beta$ between blood and brain.

Direct delivery of insulin to the hippocampus increases brain insulin and insulin signaling without modulating ISF A $\beta$ in young APP/PS1 mice

To further address the relationship between insulin signaling and ISF $\mathrm{A} \beta$, insulin was delivered directly into the hippocampus via reverse microdialysis in 3-month-old APP/PS1 mice. This approach bypassed the $\mathrm{BBB}$ to determine directly whether high insulin is capable of increasing extracellular $A \beta$ in vivo. The experimental design considered the Kd of the IR in non-neural tissues (Mosthaf et al., 1990; Weiland et al., 1991), that only a fraction of the insulin diffuses from the microdialysis probe into the surrounding tissue, and IR signaling is maximally increased by $\sim 20 \mathrm{~min}$ of exposure to high insulin in vivo (Wojtaszewski et al., 2000). Therefore, insulin was delivered at doses of 40 and $400 \mathrm{~nm}$ for $1 \mathrm{~h}$ and ipsilateral hippocampal tissue and contralateral hippocampal tissue as a control were immediately col- 
A
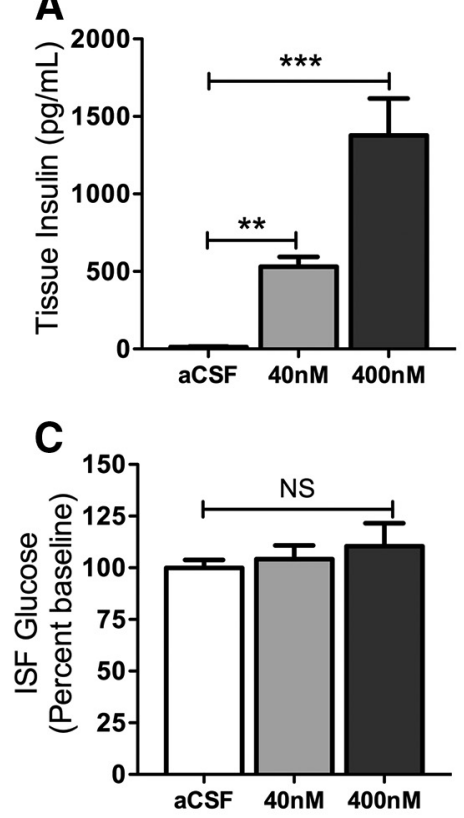

E

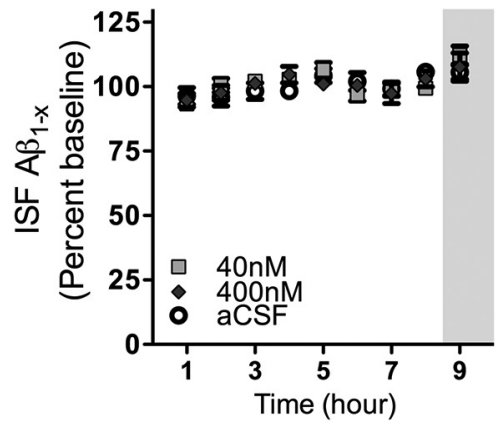

B
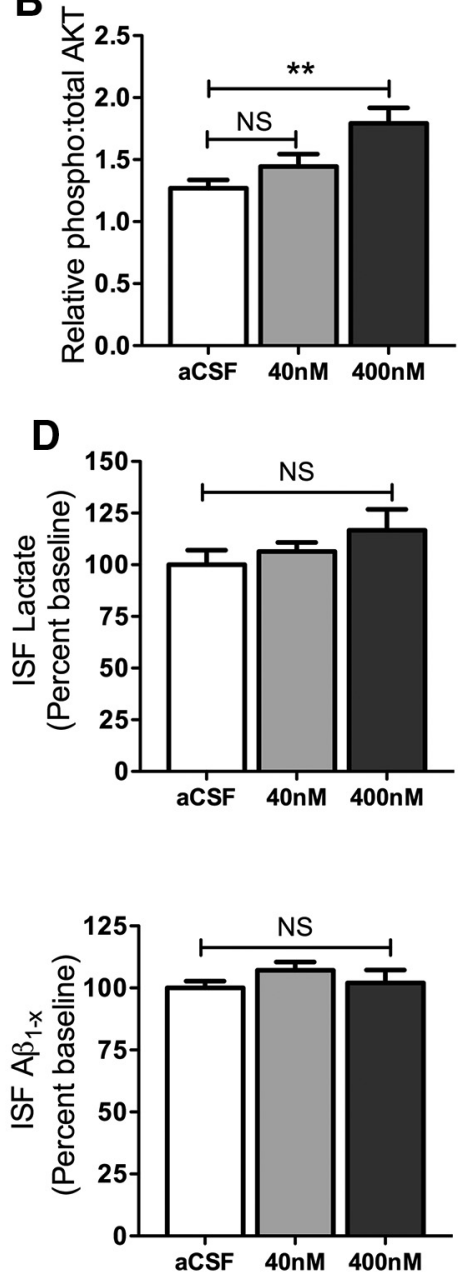

Figure 3. Direct delivery of insulin to the hippocampus increases brain insulin and insulin signaling without modulating ISF $A \beta$ in young APP/PS1 mice. $A$, Levels of tissue insulin in the left hippocampus, around the microdialysis probe, collected immediately after $1 \mathrm{~h}$ of insulin treatment or aCSF in controls ( $n=7-13$ per group). $\boldsymbol{B}$, Phospho(ser473):total AKT in the left hippocampus relative to the right hippocampus in each group after $1 \mathrm{~h}$ of insulin or aCSF treatment ( $n=7-13$ per group). C, D, ISF glucose and lactate in response to insulin or aCSF plotted as a percentage of $8 \mathrm{~h}$ of baseline $\left(n=7-13\right.$ per group). $\boldsymbol{E}$, Hourly ISF $A \beta_{1-\mathrm{x}}$ in response to insulin or aCSF (gray area) plotted as a percentage of $8 \mathrm{~h}$ of baseline, treatment hour in bar graph for comparison $(n=$ 11-24 per group). Open circles represent PBS. Gray squares represent $40 \mathrm{~nm}$. Dark gray diamonds represent $400 \mathrm{~nm}$. Data are mean \pm SEM. NS, not significant. ${ }^{* *} p<0.01,{ }^{* * *} p<0.001$ (one-way ANOVA with Dunnett's post test, $\boldsymbol{A}-\boldsymbol{E}$ ).

lected to measure tissue insulin and insulin signaling. In controls that received aCSF without insulin, insulin levels in the left hippocampus were undetectable in 9 of 11 samples. For comparison, those samples with $<10 \mathrm{pg} / \mathrm{ml}$ are plotted as $10 \mathrm{pg} / \mathrm{ml}$ (Fig. $3 A$ ). Tissue insulin was dose-dependently increased with $40 \mathrm{~nm}(\sim 40$-fold increase: $p<$ $0.01, \mathrm{q}=3.9)$ and $400 \mathrm{~nm}(\sim 100$-fold increase: $p<0.001, \mathrm{q}=8.7)$ (Fig. 3A). To determine the level of IR signaling in response to this insulin, the level of phospho:total AKT in the ipsilateral hippocampus was determined relative to the uninjected contralateral hippocampus. P-(ser473)-AKT was dose-dependently increased in the ipsilateral hippocampus with insulin compared with controls, with a significant increase at the $400 \mathrm{~nm}$ dose $(p<0.01, \mathrm{q}=3.5: 1.3 \pm 0.07$ vs $1.8 \pm 0.13$ ) (Fig. $3 B$ ). This suggests a large increase in brain insulin is necessary to detect a significant change in $\mathrm{p}-\mathrm{AKT}$ in vivo. A small increase in p-AKT was observed in the ipsilateral hippocampus in aCSF controls, likely due to the presence of the microdialysis probe, but this change was minor compared with the increase with insulin (controls: $1 \pm 0.03$ vs $1.3 \pm 0.07, p<0.05 ; 40 \mathrm{nM:} 1 \pm 0.03$ vs $1.5 \pm$
$0.1 ; 400 \mathrm{~nm}: 1 \pm 0.09$ vs $1.8 \pm 0.13$; $\operatorname{both} p<$ $0.001)$. Previous reports demonstrate that insulin delivery to the hippocampus resulted in alterations in ISF glucose and lactate (McNay et al., 2010); however, no differences in ISF glucose or lactate were detected in the injected hippocampus (Fig. $3 C, D)$. In the presence of high tissue insulin and elevated IR signaling, there was no significant differences in ISF $A \beta$ compared with $8 \mathrm{~h}$ of baseline (Fig. 3E). These experiments confirm that elevated levels of insulin and increased IR signaling are not related to higher ISF $\mathrm{A} \beta$ levels in vivo. This further supports that the modest increase in ISF A $\beta$ with hyperinsulinemic-euglycemic clamps was independent of CNS-derived neuronal IR signaling.

Changes in amyloid pathology, glucose levels, and insulin sensitivity with age in APP/PS1 mice

To determine whether the presence of $A \beta$ deposition and amyloid plaques would influence the response to peripheral or CNS-delivered insulin, 12-month-old APP/PS1 mice were used. These mice have significant amyloid pathology in both the cortex and the hippocampus compared with the 3-month-old APP/PS1 mice, which have no amyloid pathology (Fig. $4 A, B)$. Previously, we reported that baseline hippocampal ISF lactate levels were significantly increased in 12-month-old APP/PS1 mice compared with 3-monthold APP/PS1 mice (Harris et al., 2016). Here, we found that fasted blood glucose as well as hippocampal ISF glucose were lower in 12-month-old compared with 3-month-old APP/PS1 mice (blood: $p<$ $0.001, t=4.1,129.0 \pm 5$ vs $95.9 \pm 6.5$ $\mathrm{mg} / \mathrm{dl}$; ISF: $p<0.01, t=2.5,0.20 \pm 0.01$ vs $0.15 \pm 0.01 \mathrm{~mm}$ ) (Fig. $4 C, D$ ). Therefore, euglycemia for 12-month-old mice in hyperinsulinemic-euglycemic clamp experiments was lowered to $90-110 \mathrm{mg} / \mathrm{dl}$. There were no significant differences in fasted serum insulin between 3- and 12month-old APP/PS1 mice (Fig. 4E). However, there was a trend toward the 12-month-old mice being slightly insulin insensitive, determined by the glucose infusion rate during a $4 \mathrm{mU} / \mathrm{kg} / \mathrm{min}$ hyperinsulinemic-euglycemic clamp, which can be used as an indicator of how responsive the animal is to insulin $(52.9 \pm 7.6 \mathrm{vs}$ $38.9 \pm 3.8 \mathrm{mg} / \mathrm{kg} / \mathrm{min} ; p=0.13, t=1.6)($ Fig. $4 F)$.

\section{Hyperinsulinemic-euglycemic clamps do not increase} hippocampal insulin signaling but increase ISF and plasma $\mathrm{A} \beta$ in old APP/PS1 mice

Because no dose-dependent differences were observed between 4 $\mathrm{mU} / \mathrm{kg} / \mathrm{min}$ and $20 \mathrm{mU} / \mathrm{kg} / \mathrm{min}$ clamps on ISF $\mathrm{A} \beta$ in young APP/ PS1 mice, $4 \mathrm{mU} / \mathrm{kg} / \mathrm{min}$ hyperinsulinemic-euglycemic clamps were performed in the 12-month-old APP/PS1 mice to focus on the effects of physiologically relevant, postprandial levels of hyperinsulinemia. Serum insulin was significantly increased $\sim 2.6$ - 
fold from baseline in the $4 \mathrm{mU}$ clamp group $(p<0.001, t=6.4)$ and unchanged in PBS controls (Fig. 5A). There were no differences in blood glucose as it was held constant between 90 and $110 \mathrm{mg} / \mathrm{dl}$ for the duration of the clamp (Fig. 5B). ISF glucose mirrored blood glucose levels, and no changes in ISF glucose were detected (Fig. 5C). Similar to the findings in young APP/PS1 mice, there were also no changes in ISF or serum lactate (Fig. $5 D, E)$. Hyperinsulinemic-euglycemic clamps did not significantly increase CSF insulin (Fig. $5 F$ ). In these aged animals, $4 \mathrm{mU}$ insulin clamps significantly increased phospho:total AKT in the muscle as a positive control, similarly to young mice (Fig. $5 G)(1.0 \pm 0.06$ vs $1.6 \pm 0.14$ : $p<0.01, t=3.15)$. Again, there was no change in phospho:total AKT in the hippocampus (Fig. $5 H$ ). ISF $A \beta$ levels in the $4 \mathrm{mU}$ group increased from baseline (13.9 $\pm 2.2 \%)$, although PBS controls increased slightly from baseline as well $(7.8 \pm 1.8 \%)$. Overall, in aged APP/PS1 mice, ISF A $\beta$ increased by a modest $\sim 6 \%$ for the duration of the clamp when accounting for changes in PBS controls $(p=0.055, t=2.1)$ (Fig. 5I). In addition, hyperinsulinemia significantly increased plasma $\mathrm{A} \beta$ compared with $\mathrm{PBS}$ controls, even more so than in ISF $(11.9 \pm 3.6 \%$ vs $-1.1 \pm 2.7 \%$ : $p<0.05, t=2.3$ ) (Fig. $5 J$ ). Therefore, physiological hyperinsulinemia appears to modestly increase ISF and significantly increase plasma $\mathrm{A} \beta$ in aged $A P P / P S 1$ mice, similar to young APP/PS1 mice, despite no change in hippocampal insulin signaling. These results point to a potential peripheral mechanism of hyperinsulinemia that could potentially modulate the net transport of $A \beta$ between blood and brain to modulate ISF $A \beta$ independent of neuronal insulin signaling.

\section{Direct delivery of insulin to the hippocampus increases brain insulin and insulin signaling without modulating ISF A $\beta$ in old $A P P / P S 1$ mice}

Insulin was delivered directly into the hippocampus via reverse microdialysis in 12month-old APP/PS1 mice to determine the effects on insulin signaling and ISF $A \beta$, as well as to determine whether the aged APP/PS1 brain with significant plaque pathology is still sensitive to insulin. Based on the dose-response in 3-month-old mice (Fig. 3A,B), $400 \mathrm{~nm}$ insulin was delivered to the hippocampus because this dose significantly elevated phospho:total AKT in young mice. In 12-month-old mice, tissue insulin levels in control hippocampi were undetectable in 1 of 7 samples (plotted as $10 \mathrm{pg} / \mathrm{ml}$ for comparison). Similar to young APP/PS1 mice, tissue insulin was significantly increased with insulin treatment $(\sim 40$-fold: $p<0.001, t=4.8)$ (Fig. 6 A). Phos-
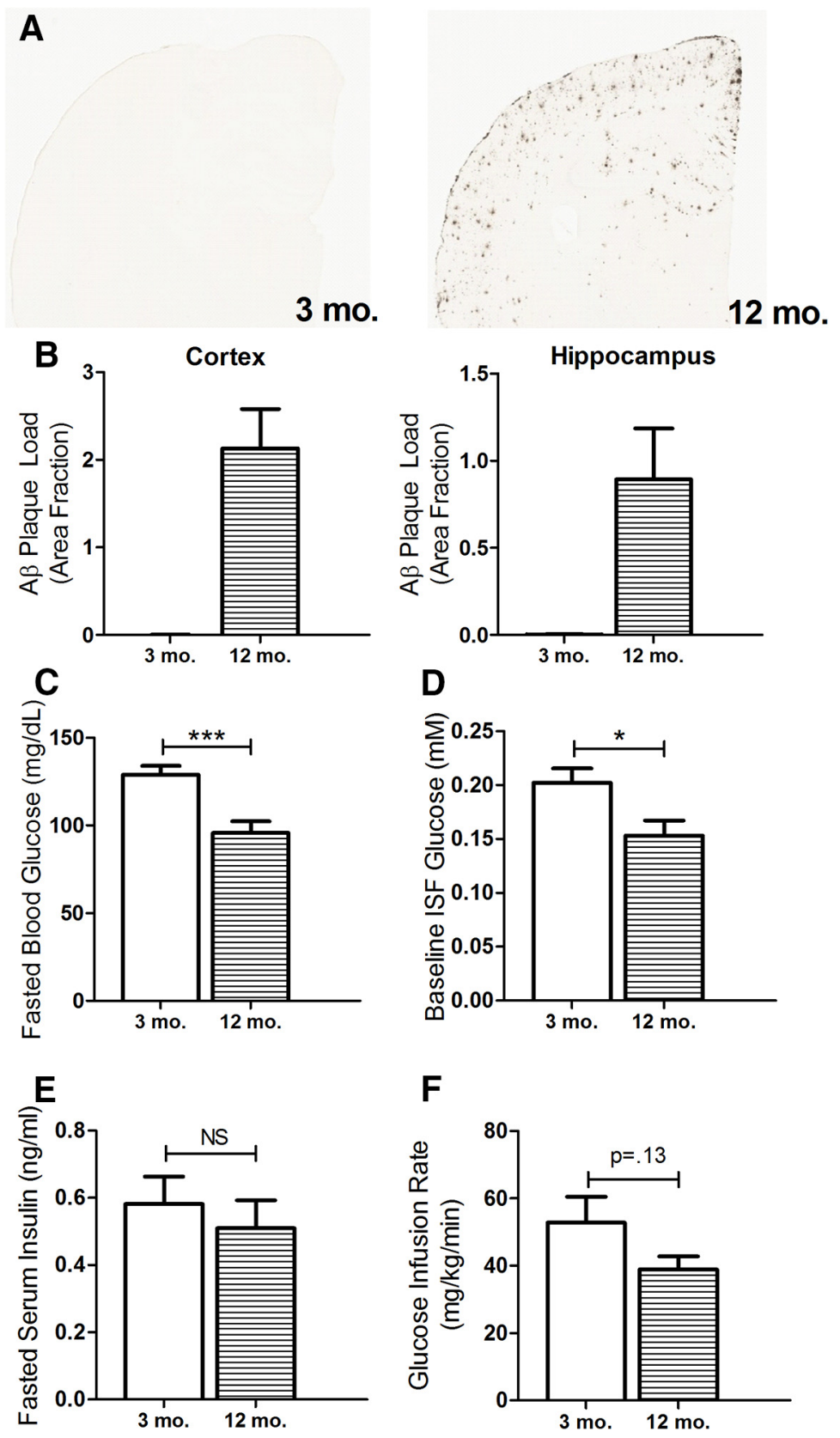

Figure 4. Changes in amyloid pathology, glucose levels, and insulin sensitivity with age in APP/PS1 mice. $\boldsymbol{A}$, Representative images of $A \beta$ plaque staining in brain slices from 3-and 12-month-old APP/PS1 mice. $B$, Quantification of $A \beta$ staining: 3-monthold had zero reactivity; therefore, statistics could not be run ( $n=5$ per group). $C$, Fasting blood glucose levels measured at baseline before clamps in 3-and 12-month-old APP/PS1 mice ( $n=15-21$ per group). D, Average ISF glucose during $8 \mathrm{~h}$ of baseline in 3-and 12-month-old APP/PS1 mice ( $n=14-19$ per group). $\boldsymbol{E}$, Fasted serum insulin measured at baseline before clamps in 3- and 12-month-old APP/PS1 mice ( $n=15-21$ per group). $\boldsymbol{F}$, Average glucose infusion rate during a 4 mU hyperinsulinemic-euglycemic clamp in 3- and 12-month-old APP/PS1 mice, an indicator of insulin sensitivity ( $n=7$ per group). Data are mean \pm SEM. NS, not significant. ${ }^{*} p<0.05,{ }^{* * *} p<0.001$ (unpaired, two-tailed $t$ test, $\boldsymbol{C}-\boldsymbol{F}$ ).

pho:total AKT was measured in the ipsilateral, injected hippocampus relative to the contralateral hippocampus to control for any changes the probe might have on intracellular signaling. A significant increase in phospho:total AKT in response to $400 \mathrm{~nm}$ insulin was observed compared with control mice $(p<$ $0.001, t=6.9: 1.23 \pm 0.05$ vs $2.12 \pm 0.13$ ) (Fig. $6 B$ ), which is a slightly larger response compared with 3-month-old mice (Fig. $3 B$ ). Again, the presence of a probe led to a small increase in $\mathrm{p}$-AKT in the ipsilateral hippocampus compared with the contralateral for controls, but this was minor compared with the 

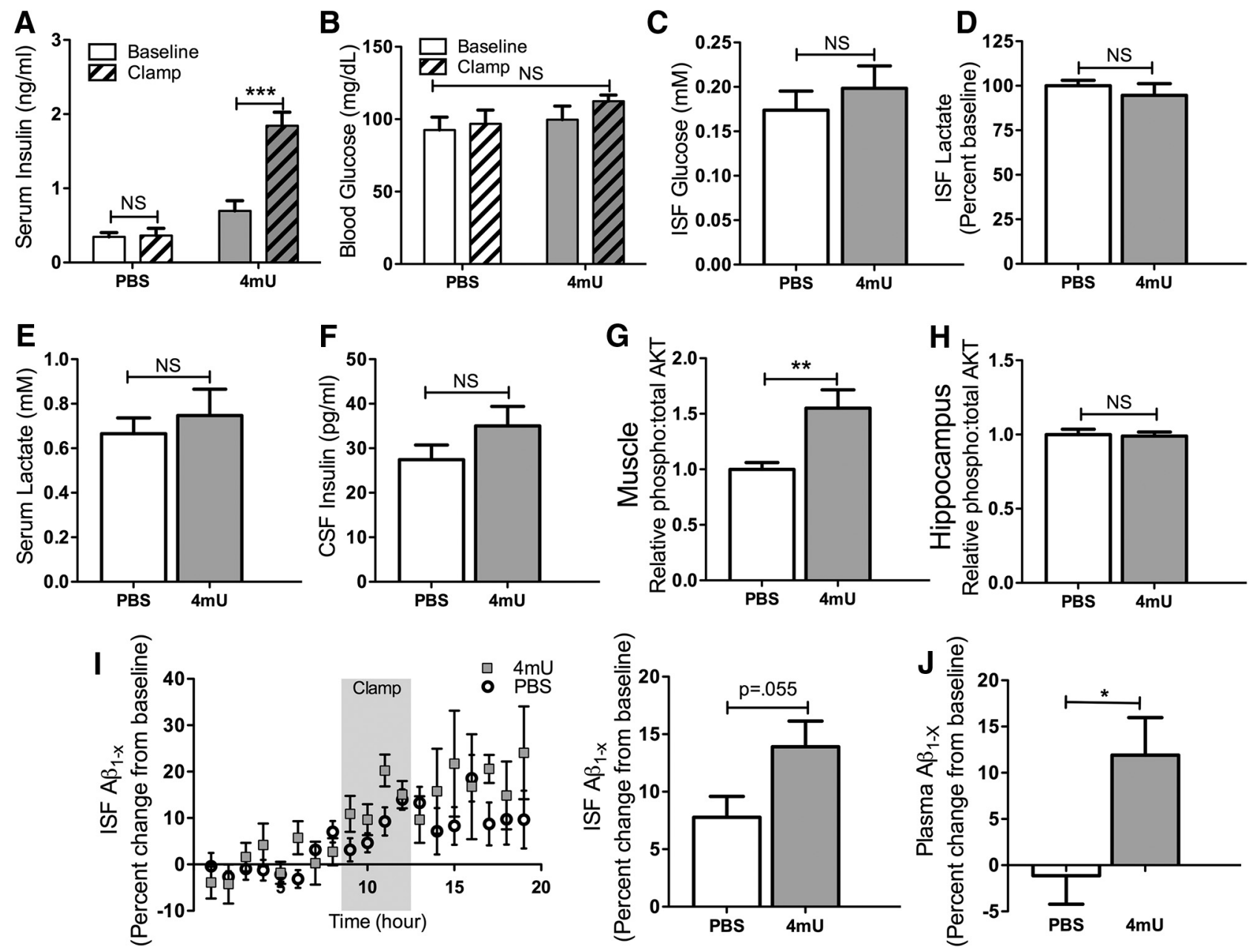

Figure 5. Hyperinsulinemic-euglycemic clamps do not increase hippocampal insulin signaling but increase ISF and plasma A $\beta$ in old APP/PS1 mice. A, Serum insulin levels at fasted baseline (solid) and during hyperinsulinemic-euglycemic or PBS clamps (striped) ( $n=7$ per group). $\boldsymbol{B}$, Blood glucose levels at fasted baseline and average during the clamps: blood glucose was clamped between $90 \mathrm{and} 110 \mathrm{mg} / \mathrm{dl}$ at euglycemic levels throughout the clamps to ensure that there were no changes between baseline and clamp in any condition ( $n=7 \mathrm{per} \mathrm{group).} \mathrm{C}$, ISF glucose levels during the clamps ( $n=6$ or 7 per group). D, ISF lactate during the clamps as a percentage of $8 \mathrm{~h}$ of baseline ( $n=6$ or 7 per group). $\boldsymbol{E}$, Serum lactate levels during the clamps ( $n=4$ or 5 per group). $\boldsymbol{F}$, CSF insulin in samples collected immediately after 1-1.5 h of clamp ( $n=7-9$ per group). $\mathbf{G}, \boldsymbol{H}$, Phospho(ser473):total AKT in leg muscle and hippocampus collected after $1 \mathrm{~h}$ of $4 \mathrm{mU}$ or PBS clamp. Normalized to PBS controls ( $n=7-9$ per group). I, Hourly ISF A $\beta_{1-x}$ measurements during $8 \mathrm{~h}$ of baseline, $4 \mathrm{~h}$ of clamp, and $8 \mathrm{~h}$ after clamp plotted as percentage change from baseline. 0 pen circles represent PBS. Gray squares represent $4 \mathrm{mU}$. Average ISF A $\beta_{1-x}$ during the $4 \mathrm{~h}$ clamp was used to compare the effect of hyperinsulinemia on ISF $A \beta_{1-x}$ compared with PBS controls ( $n=7$ per group). $J$, Plasma $A \beta_{1-x}$ plotted as percentage change from baseline. Baseline samples were collected after fasting and clamp samples collected $1 \mathrm{~h}$ into clamp $(n=5-8$ per group). Data are mean \pm SEM. NS, not significant. ${ }^{*} p<0.05,{ }^{* *} p<0.01,{ }^{* * *} p<0.001$ (two-way ANOVA with Bonferroni post test, $\boldsymbol{A}, \boldsymbol{B}$; or unpaired, two-tailed $t$ test, $(-J)$.

change with insulin (controls: $1.0 \pm 0.02$ vs $1.23 \pm 0.05, p<$ $0.05 ; 400 \mathrm{nm:} 1.0 \pm 0.06$ vs $2.12 \pm 0.13, p<0.001)$. This suggests that the hippocampus is not insulin resistant in the presence of significant amyloid pathology. To confirm that the presence of amyloid plaques did not affect brain insulin sensitivity, we repeated this experiment in age-matched wild-type (WT) mice and found a significant, equivalent increase in $\mathrm{p}$-AKT in response to $400 \mathrm{~nm}$ insulin $(p<0.001, t=7.8$ : $1.32 \pm 0.07$ vs $2.07 \pm 0.07$ ) (Fig. $6 C$ ). Despite high tissue insulin and insulin signaling, there was no change in ISF glucose or lactate in response to insulin (Fig. $6 D, E$ ). There was also no increase in ISF $A \beta$ in response to the hippocampal insulin infusion (Fig. $6 F$ ). These results suggest that the presence of amyloid pathology does not influence the ability of insulin to increase IR signaling, contribute to insulindependent glucose uptake, or modulate $\mathrm{A} \beta$. Comparing peripheral to central high insulin in aged APP/PS1 mice, these data again suggest that the subtle increase in ISF $A \beta$ with peripheral clamps is independent of CNS neuronal IR signaling.

Phospho:total AKT is conventionally measured by Western blot; but in the above experiments, we used a commercially available ELISA kit, which offered a platform for higher throughput, reduced variability, higher sensitivity, and more quantitative results. To confirm that this ELISA agrees with the conventional method of Western blot, we measured phospho:total AKT in the same samples by Western blot and ELISA in 12-month-old WT mice in response to $400 \mathrm{~nm}$ insulin or aCSF as a control. Both methods detected a significant increase in $\mathrm{p}$-AKT with insulin to the same degree (both $p<$ $0.01: 1 \pm 0.05$ vs $1.5 \pm 0.05$ by ELISA $(t=4.4), 1 \pm 0.04$ vs $1.4 \pm 0.14$ by Western $(t=3.5)$ (Fig. 6G). This confirms our method and validates the reported p-AKT data.

\section{Discussion}

The goal of the studies described herein was twofold. First, we sought to elucidate the effects of systemic, physiological hyperin- 

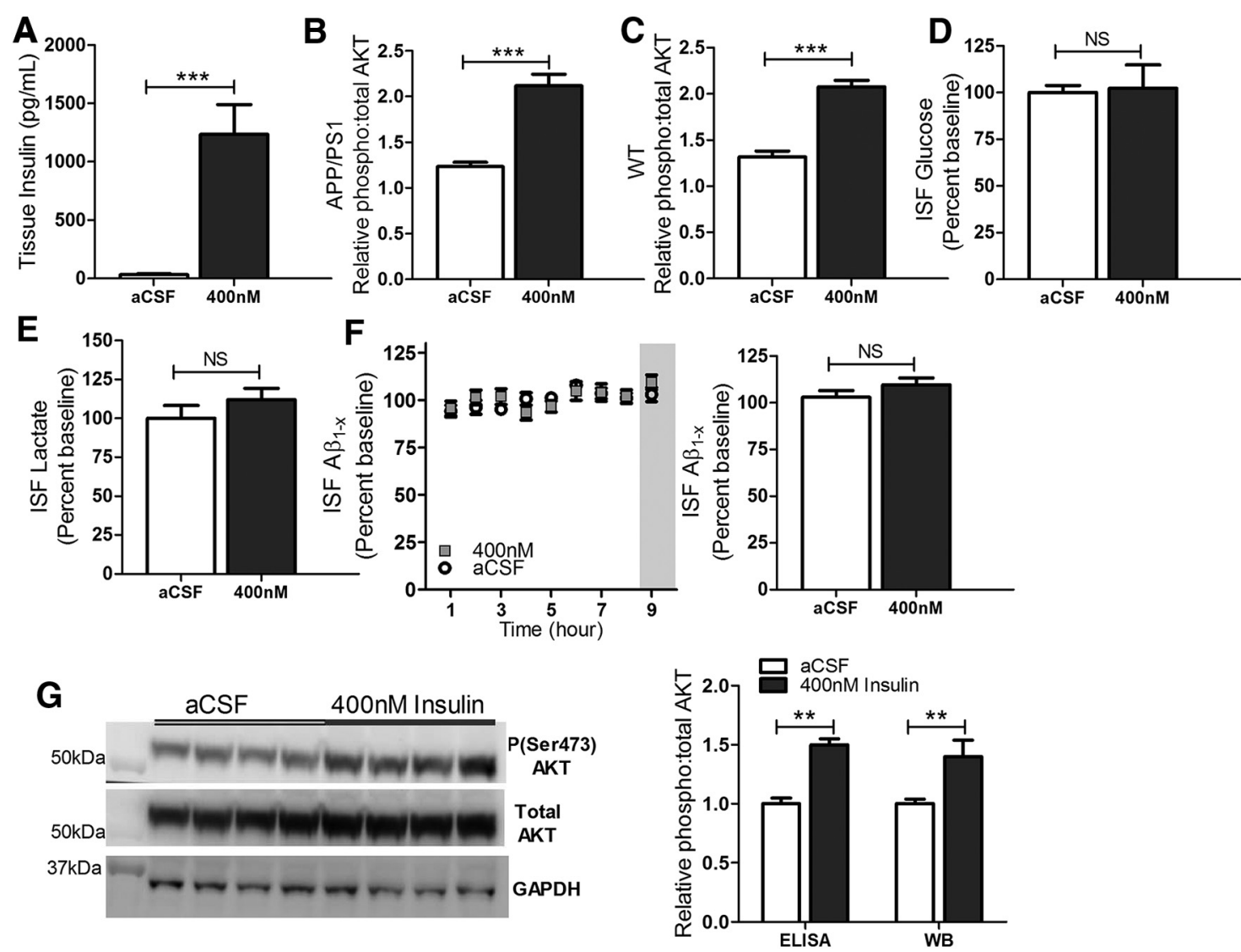

Figure 6. Direct delivery of insulin to the hippocampus increases brain insulin and insulin signaling without modulating ISF A $\beta$ in old APP/PS1 mice. $A$, Levels of tissue insulin in the left hippocampus, around the microdialysis probe, collected immediately after $1 \mathrm{~h}$ of insulin treatment or aCSF in controls ( $n=7$ per group). $\boldsymbol{B}$, Phospho(ser473):total AKT in the left hippocampus relative to the right hippocampus in each group after $1 \mathrm{~h}$ of insulin or aCSF treatment in APP/PS1 mice ( $n=9$ or 10 per group). C, Phospho(ser473):total AKT in the left hippocampus relative to the right hippocampus in each group after $1 \mathrm{~h}$ of insulin or aCSF treatment in age-matched wild-type mice ( $n=4$ per group). $\boldsymbol{D}, \boldsymbol{E}$, ISF glucose and lactate in response to insulin or aCSF plotted as a percentage of $8 \mathrm{~h}$ of baseline ( $n=7-10$ per group). $\boldsymbol{F}$, Hourly ISF $A \beta_{1-x}$ in response to insulin or aCSF (gray area) plotted as a percentage of $8 \mathrm{~h}$ of baseline, treatment hour in bar graph for comparison ( $n=9-11$ per group). Open circles represent PBS. Dark gray diamonds represent $400 \mathrm{~nm}$. G, Phospho:total AKT Western blot (WB) from hippocampal lysates of 12-month-0ld WT mice receiving 400 $\mathrm{nm}$ insulin or aCSF via reverse microdialysis. Data are quantified in the graph on the right (WB) and compared with the same samples quantified by AKT ELISA ( $n=4$ per group). Data are mean \pm SEM. NS, not significant. ${ }^{* *} p<0.01,{ }^{* * *} p<0.001$ (unpaired, two-tailed $t$ test, $\boldsymbol{A - F}$; or two-way ANOVA with Bonferroni post test, $\mathbf{G}$ ).

sulinemia on insulin levels and insulin signaling in the brain of awake, behaving mice. Questions remain regarding the transport of insulin across the BBB and how systemic changes in blood insulin levels affect neuronal insulin signaling. By combining hyperinsulinemic-euglycemic clamps with hippocampal microdialysis in vivo, we are able to directly investigate how peripheral changes in metabolism dynamically alter metabolites within the brain ISF. Second, we investigated whether high levels of peripheral and CNS-administered insulin could affect ISF A $\beta$ levels and shed light on the complex relationship between insulin and AD. Although widely studied, the roles of insulin as both a pathological molecule and potential therapeutic in AD still remain poorly understood. Combining clamps and in vivo microdialysis, we have the ability to investigate the dynamic effects of insulin on molecules relevant to the pathogenesis of $\mathrm{AD}$, such as $\mathrm{A} \beta$. These experiments found that peripherally high insulin does not acutely increase insulin levels or insulin signaling within the brain, whereas direct administration of insulin into the hippocampus increases insulin levels and insulin signaling, even in the presence of amyloid plaques. As it relates to $A \beta$, peripheral hyperinsulinemia modestly increased ISF $A \beta$, whereas central administration did not. Peripheral hyperinsulinemia also significantly increased plasma $\mathrm{A} \beta$ to a greater extent than in the ISF, pointing to a possible mechanism that can influence the net transport of $\mathrm{A} \beta$
Table 1. Summary of the effects of peripheral and central high insulin on hippocampal IR signaling and ISF $A \beta$ in young and old APP/PS1 mice ${ }^{a}$

\begin{tabular}{lll}
\hline & Hippocampal IR signaling & Hippocampal ISF $A \beta$ \\
\hline Peripheral high insulin: $4 \mathrm{mU} / \mathrm{kg} / \mathrm{min}$ & & \\
3 months old & No change & $\uparrow 9 \%$ versus controls \\
12 months old & No change & $\uparrow 6 \%$ versus controls \\
CNS high insulin: $400 \mathrm{~nm}$ & & \\
3 months old & $\uparrow 50 \%$ versus controls & No change \\
12 months old & $\uparrow 70 \%$ versus controls & No change \\
\hline
\end{tabular}

${ }^{a}$ Comparing postprandial ( $4 \mathrm{mU} / \mathrm{kg} / \mathrm{min}$ ) peripheral hyperinsulinemia and hippocampal infusion of insulin ( $400 \mathrm{~nm}$ ) on hippocampal IR signaling and ISF $A \beta$ demonstrates a novel disconnect between neuronal IR signaling and extracellular $A \beta$. The overall relationship between peripheral and central insulin, signaling, and $A \beta$ does not differ in the presence of significant amyloid pathology.

between blood and brain to modulate ISF $\mathrm{A} \beta$ without changing neuronal IR signaling. Our results suggest a novel disconnect between neuronal IR signaling and extracellular $\mathrm{A} \beta$ levels in vivo, contrary to previous studies in vitro (Gasparini et al., 2001). Results are summarized in Table 1.

Elucidating the complete mechanism behind the modest increase in ISF $\mathrm{A} \beta$ with peripheral hyperinsulinemia using in vivo techniques is difficult, but we have demonstrated that the mechanism is independent of CNS neuronal IR signaling and IDE activity in the hippocampus. The simultaneous increase in 
plasma $A \beta$, along with the fact that we could not detect any changes in CNS insulin or insulin signaling, suggests that high blood insulin may be acting peripherally to modulate $A \beta$ levels and its net transport across the BBB. Plasma $\mathrm{A} \beta$ has been shown to increase CNS A $\beta$ (Maness et al., 1994; Martel et al., 1996; Deane et al., 2003) and potentially have a significant impact on the development of brain amyloid pathology (DeMattos et al., 2001). It is also possible that an unidentified, peripheral molecule could change in response to peripheral hyperinsulinemia and affect $\mathrm{A} \beta$ levels by crossing the $\mathrm{BBB}$ to act directly on brain tissue, affect the $\mathrm{BBB}$ transport of $\mathrm{A} \beta$ without crossing into the CNS, or affect cells in the brain to modify glymphatic clearance (Xie et al., 2013) to ultimately alter $A \beta$ levels. Because we found no change in ISF lactate in response to peripheral hyperinsulinemia, we can conclude that the mechanism is also independent of increased neuronal activity: a phenomenon that increases both lactate and A $\beta$ in ISF (Bero et al., 2011). Therefore, the mechanism behind the increase in $\mathrm{A} \beta$ with high blood insulin is independent of neuronal IR signaling, hippocampal IDE degradation, and neuronal activity but appears to alter the net flux of $A \beta$ across the BBB.

Our findings are of interest since we previously demonstrated that hyperglycemic clamps increase ISF A $\beta$ using similar methodologies (Macauley et al., 2015). Hyperglycemia, another key feature of T2D, may negatively affect the brain and impact $\mathrm{A} \beta$ pathology even more than insulin. We reported that doubling blood and ISF glucose with hyperglycemic clamps significantly increased ISF A $\beta \sim 27 \%$ in young and $\sim 40 \%$ in aged APP/PS1 mice (Macauley et al., 2015). In these experiments, insulin was also increased threefold in response to the hyperglycemia, so the current experiments delineate the specific role of blood insulin in modulating ISF $A \beta$ and shows that insulin does contribute to the increase in $A \beta$, although to a lesser extent than glucose. In patients with $\mathrm{T} 2 \mathrm{D}$, these pathologies overlap temporally and over years of prediabetes and T2D, high blood glucose and insulin likely influence the onset or progression of $\mathrm{AD}$ by modulating $\mathrm{A} \beta$ levels in the brain ISF and plasma. We previously saw an exaggerated response in ISF $A \beta$ to hyperglycemia in aged mice with significant amyloid pathology (Macauley et al., 2015). Here, we report new found differences at baseline in blood and ISF glucose between young and aged APP/PS1 mice that correspond with changes in lactate that we previously reported (Harris et al., 2016). Conversely, there was no baseline difference in blood insulin levels, which may explain why we saw an exaggerated response to hyperglycemia in aged mice but a similar response to insulin. One explanation for why blood glucose has a more robust effect on ISF A $\beta$ than blood insulin is that glucose readily crosses the BBB through highly abundant glucose transporter 1 to mirror the level of glucose in the blood and act directly on brain cells, modulating neuronal activity (Macauley et al., 2015). Insulin crosses the BBB through a limited number of IRs on endothelial cells (Zuchero et al., 2016) with saturation at physiological levels, and we found no evidence of increased CNS insulin in response to peripherally high insulin. In summary, we have now shown that both high blood glucose and insulin can independently elevate ISF $\mathrm{A} \beta$ levels and potentially link $\mathrm{T} 2 \mathrm{D}$ and $\mathrm{AD}$ through distinct mechanisms.

The only experiments to date detecting a significant increase in brain IR signaling in response to peripherally high insulin use a protocol where mice are injected with extreme, supraphysiological insulin, directly into the vena cava after overnight fast while under anesthesia (Clodfelder-Miller et al., 2005; Freude et al., 2005; Dummler et al., 2006; Sartorius et al., 2015; Sajan et al.,
2016). Even under these extreme conditions, the change in IR signaling, such as p-AKT, is relatively unchanged compared with peripheral tissues (Dummler et al., 2006). Overnight fasting, because mice are nocturnal, reduces blood insulin and glucose significantly more than an acute fast, and reduces fat and muscle content and hepatic glycogen (Ayala et al., 2006). An overnight fast also reduces p-AKT in the hippocampus and cortex of mice (Clodfelder-Miller et al., 2005). Thus, the only way to detect an increase in brain IR signaling with peripherally high insulin seems to be after basal signaling is reduced and extreme insulin injections are used. Our experiments are crucial to understanding the role of physiological changes in blood insulin on the brain, finding that postprandial hyperinsulinemia, after $4-5 \mathrm{~h}$ of fasting in awake, behaving animals did not change brain IR signaling or insulin levels. Our acute experiments could not detect a change in insulin transportation, but with chronic, physiological alterations seen with $\mathrm{T} 2 \mathrm{D}, \mathrm{AD}$, obesity, or aging, there may be altered transport of insulin from blood to CNS (Fujisawa et al., 1991; Craft et al., 1998; Banks, 2004; Sartorius et al., 2015; Sajan et al., 2016).

Another important finding is related to the idea that the brain becomes insulin-resistant in $\mathrm{AD}$ due to toxic $\mathrm{A} \beta$ species. By delivering insulin directly into the hippocampus and measuring insulin signaling, we were able to demonstrate in vivo that a brain with significant amounts of endogenous $\mathrm{A} \beta$ monomers, aggregates, and amyloid plaques is still responsive to insulin. Aged APP/PS1 mice reportedly have high levels of p(ser)-IRS1, a specific component of the IR signaling cascade that correlates with insulin resistance (Bomfim et al., 2012). Postmortem brains from $\mathrm{AD}$ patients have higher levels of $\mathrm{p}(\mathrm{ser})$-IRS1 and reduced ex vivo insulin stimulation compared with controls (Moloney et al., 2010; Bomfim et al., 2012; Talbot et al., 2012; Yarchoan et al., 2014). Moreover, neuronal insulin resistance is thought to be due to the presence of $\mathrm{A} \beta$, particularly $\mathrm{A} \beta$ oligomers (Zhao et al., 2008; De Felice et al., 2009; Bomfim et al., 2012). Although $\mathrm{p}$ (ser)-IRS1 was not measured directly in our studies, our results show that the aged, APP/PS1 mouse brain is equally responsive to insulin as a wild-type mouse with no plaques and as a young APP/PS1 mouse before amyloid plaque deposition. If intranasal insulin is improving memory by increasing insulin signaling, these results suggest that a brain with $\mathrm{A} \beta$ aggregates could still respond positively to treatment.

Overall, we were able to show that acute, peripheral hyperinsulinemia increases plasma and ISF $\mathrm{A} \beta$ in both young and old APP/PS1 mice, likely through a peripheral mechanism, independent of neuronal insulin signaling, IDE degradation, and neuronal activity in the hippocampus. These results shed light on the causal relationship between peripheral hyperinsulinemia, a key feature of $\mathrm{T} 2 \mathrm{D}$, and $\mathrm{A} \beta$ pathology in $\mathrm{AD}$ pathogenesis. In addition, we found that direct delivery of insulin to the hippocampus increased neuronal insulin signaling, even in the presence of amyloid plaques, but did not have any effect on ISF A $\beta$ levels. These results support the potential use of intranasal insulin as an $\mathrm{AD}$ therapeutic and highlight how modulating insulin levels in the brain specifically, compared with the blood, can have differential effects on extracellular $\mathrm{A} \beta$ in the brain.

\section{References}

Ayala JE, Bracy DP, McGuinness OP, Wasserman DH (2006) Considerations in the design of hyperinsulinemic-euglycemic clamps in the conscious mouse. Diabetes 55:390-397. CrossRef Medline

Banks WA (2004) The source of cerebral insulin. Eur J Pharmacol 490:5-12. CrossRef Medline

Banks WA, Jaspan JB, Kastin AJ (1997) Selective, physiological transport of 
insulin across the blood-brain barrier: novel demonstration by speciesspecific radioimmunoassays. Peptides 18:1257-1262. CrossRef Medline

Baura GD, Foster DM, Porte D Jr, Kahn SE, Bergman RN, Cobelli C, Schwartz MW (1993) Saturable transport of insulin from plasma into the central nervous system of dogs in vivo: a mechanism for regulated insulin delivery to the brain. J Clin Invest 92:1824-1830. CrossRef Medline

Berhane F, Fite A, Daboul N, Al-Janabi W, Msallaty Z, Caruso M, Lewis MK, Yi Z, Diamond MP, Abou-Samra AB, Seyoum B (2015) Plasma lactate levels increase during hyperinsulinemic euglycemic clamp and oral glucose tolerance test. J Diabetes Res 2015:102054. CrossRef Medline

Bero AW, Yan P, Roh JH, Cirrito JR, Stewart FR, Raichle ME, Lee JM, Holtzman DM (2011) Neuronal activity regulates the regional vulnerability to amyloid-beta deposition. Nat Neurosci 14:750-756. CrossRef Medline

Bomfim TR, Forny-Germano L, Sathler LB, Brito-Moreira J, Houzel JC, Decker H, Silverman MA, Kazi H, Melo HM, McClean PL, Holscher C, Arnold SE, Talbot K, Klein WL, Munoz DP, Ferreira ST, De Felice FG (2012) An anti-diabetes agent protects the mouse brain from defective insulin signaling caused by Alzheimer's disease-associated Abeta oligomers. J Clin Invest 122:1339-1353. CrossRef Medline

Borchelt DR, Ratovitski T, van Lare J, Lee MK, Gonzales V, Jenkins NA, Copeland NG, Price DL, Sisodia SS (1997) Accelerated amyloid deposition in the brains of transgenic mice coexpressing mutant presenilin 1 and amyloid precursor proteins. Neuron 19:939-945. CrossRef Medline

Cirrito JR, May PC, O’Dell MA, Taylor JW, Parsadanian M, Cramer JW, Audia JE, Nissen JS, Bales KR, Paul SM, DeMattos RB, Holtzman DM (2003) In vivo assessment of brain interstitial fluid with microdialysis reveals plaque-associated changes in amyloid-beta metabolism and halflife. J Neurosci 23:8844-8853. Medline

Clodfelder-Miller B, De Sarno P, Zmijewska AA, Song L, Jope RS (2005) Physiological and pathological changes in glucose regulate brain Akt and glycogen synthase kinase-3. J Biol Chem 280:39723-39731. CrossRef Medline

Craft S, Peskind E, Schwartz MW, Schellenberg GD, Raskind M, Porte D Jr (1998) Cerebrospinal fluid and plasma insulin levels in Alzheimer's disease: relationship to severity of dementia and apolipoprotein E genotype. Neurology 50:164-168. CrossRef Medline

Deane R, Du Yan S, Submamaryan RK, LaRue B, Jovanovic S, Hogg E, Welch D, Manness L, Lin C, Yu J, Zhu H, Ghiso J, Frangione B, Stern A, Schmidt AM, Armstrong DL, Arnold B, Liliensiek B, Nawroth P, Hofman F, et al. (2003) RAGE mediates amyloid-beta peptide transport across the blood-brain barrier and accumulation in brain. Nat Med 9:907-913. CrossRef Medline

De Felice FG, Vieira MN, Bomfim TR, Decker H, Velasco PT, Lambert MP, Viola KL, Zhao WQ, Ferreira ST, Klein WL (2009) Protection of synapses against Alzheimer's-linked toxins: insulin signaling prevents the pathogenic binding of Abeta oligomers. Proc Natl Acad Sci U S A 106: 1971-1976. CrossRef Medline

DeMattos RB, Bales KR, Cummins DJ, Dodart JC, Paul SM, Holtzman DM (2001) Peripheral anti-A beta antibody alters CNS and plasma A beta clearance and decreases brain A beta burden in a mouse model of Alzheimer's disease. Proc Natl Acad Sci U S A 98:8850-8855. CrossRef Medline

Dummler B, Tschopp O, Hynx D, Yang ZZ, Dirnhofer S, Hemmings BA (2006) Life with a single isoform of Akt: mice lacking Akt2 and Akt3 are viable but display impaired glucose homeostasis and growth deficiencies. Mol Cell Biol 26:8042-8051. CrossRef Medline

Fishel MA, Watson GS, Montine TJ, Wang Q, Green PS, Kulstad JJ, Cook DG, Peskind ER, Baker LD, Goldgaber D, Nie W, Asthana S, Plymate SR, Schwartz MW, Craft S (2005) Hyperinsulinemia provokes synchronous increases in central inflammation and beta-amyloid in normal adults. Arch Neurol 62:1539-1544. CrossRef Medline

Freude S, Plum L, Schnitker J, Leeser U, Udelhoven M, Krone W, Bruning JC, Schubert M (2005) Peripheral hyperinsulinemia promotes tau phosphorylation in vivo. Diabetes 54:3343-3348. CrossRef Medline

Fujisawa Y, Sasaki K, Akiyama K (1991) Increased insulin levels after OGTT load in peripheral blood and cerebrospinal fluid of patients with dementia of Alzheimer type. Biol Psychiatry 30:1219-1228. CrossRef Medline

Gasparini L, Gouras GK, Wang R, Gross RS, Beal MF, Greengard P, Xu H (2001) Stimulation of beta-amyloid precursor protein trafficking by insulin reduces intraneuronal beta-amyloid and requires mitogen-activated protein kinase signaling. J Neurosci 21:2561-2570. Medline

Harris RA, Tindale L, Lone A, Singh O, Macauley SL, Stanley M, Holtzman DM, Bartha R, Cumming RC (2016) Aerobic glycolysis in the frontal cortex correlates with memory performance in wild-type mice but not the APP/PS1 mouse model of cerebral amyloidosis. J Neurosci 36:1871-1878. CrossRef Medline

Holtzman DM, Morris JC, Goate AM (2011) Alzheimer's disease: the challenge of the second century. Sci Transl Med 3:3002369. CrossRef Medline

Kuusisto J, Koivisto K, Mykkanen L, Helkala EL, Vanhanen M, Hanninen T, Kervinen K, Kesaniemi YA, Riekkinen PJ, Laakso M (1997) Association between features of the insulin resistance syndrome and Alzheimer's disease independently of apolipoprotein E4 phenotype: cross sectional population based study. Br Med J 315:1045-1049. CrossRef Medline

Luchsinger JA, Tang MX, Shea S, Mayeux R (2004) Hyperinsulinemia and risk of Alzheimer disease. Neurology 63:1187-1192. CrossRef Medline

Ma J, Zhang W, Wang HF, Wang ZX, Jiang T, Tan MS, Yu JT, Tan L (2016) Peripheral blood adipokines and insulin levels in patients with Alzheimer's disease: a replication study and meta-analysis. Curr Alzheimer Res 13:223-233. CrossRef Medline

Macauley SL, Stanley M, Caesar EE, Yamada SA, Raichle ME, Perez R, Mahan TE, Sutphen CL, Holtzman DM (2015) Hyperglycemia modulates extracellular amyloid-beta concentrations and neuronal activity in vivo. J Clin Invest 125:2463-2467. CrossRef Medline

Maness LM, Banks WA, Podlisny MB, Selkoe DJ, Kastin AJ (1994) Passage of human amyloid $\beta$-protein 1-40 across the murine blood-brain barrier. Life Sci 55:1643-1650. CrossRef Medline

Martel CL, Mackic JB, McComb JG, Ghiso J, Zlokovic BV (1996) Bloodbrain barrier uptake of the 40 and 42 amino acid sequences of circulating Alzheimer's amyloid beta in guinea pigs. Neurosci Lett 206:157-160. CrossRef Medline

McNay EC, Ong CT, McCrimmon RJ, Cresswell J, Bogan JS, Sherwin RS (2010) Hippocampal memory processes are modulated by insulin and high-fat-induced insulin resistance. Neurobiol Learn Mem 93:546-553. CrossRef Medline

Mehran AE, Templeman NM, Brigidi GS, Lim GE, Chu KY, Hu X, Botezelli JD, Asadi A, Hoffman BG, Kieffer TJ, Bamji SX, Clee SM, Johnson JD (2012) Hyperinsulinemia drives diet-induced obesity independently of brain insulin production. Cell Metab 16:723-737. CrossRef Medline

Moloney AM, Griffin RJ, Timmons S, O’Connor R, Ravid R, O’Neill C (2010) Defects in IGF-1 receptor, insulin receptor and IRS-1/2 in Alzheimer's disease indicate possible resistance to IGF-1 and insulin signalling. Neurobiol Aging 31:224-243. CrossRef Medline

Mosthaf L, Grako K, Dull TJ, Coussens L, Ullrich A, McClain DA (1990) Functionally distinct insulin receptors generated by tissue-specific alternative splicing. EMBO J 9:2409-2413. Medline

Musiek ES, Holtzman DM (2015) Three dimensions of the amyloid hypothesis: time, space and 'wingmen.' Nat Neurosci 18:800-806. CrossRef Medline

Pandini G, Pace V, Copani A, Squatrito S, Milardi D, Vigneri R (2013) Insulin has multiple antiamyloidogenic effects on human neuronal cells. Endocrinology 154:375-387. CrossRef Medline

Plum L, Schubert M, Brüning JC (2005) The role of insulin receptor signaling in the brain. Trends Endocrinol Metab 16:59-65. CrossRef Medline

Qiu WQ, Walsh DM, Ye Z, Vekrellis K, Zhang J, Podlisny MB, Rosner MR, Safavi A, Hersh LB, Selkoe DJ (1998) Insulin-degrading enzyme regulates extracellular levels of amyloid beta-protein by degradation. J Biol Chem 273:32730-32738. CrossRef Medline

Sajan M, Hansen B, Ivey R 3rd, Sajan J, Ari C, Song S, Braun U, Leitges M, Farese-Higgs M, Farese RV (2016) Brain insulin signaling is increased in insulin-resistant states and decreases in FoxOs and PGC-1alpha and increases in Abeta 1-40.42 and phospho-tau may abet Alzheimer development. Diabetes 65:1892-1903. CrossRef Medline

Sartorius T, Peter A, Heni M, Maetzler W, Fritsche A, Häring HU, Hennige AM (2015) The brain response to peripheral insulin declines with age: a contribution of the blood-brain barrier? PLoS One 10:e0126804. CrossRef Medline

Selkoe DJ (2004) Cell biology of protein misfolding: the examples of Alzheimer's and Parkinson's diseases. Nat Cell Biol 6:1054-1061. CrossRef Medline

Shiiki T, Ohtsuki S, Kurihara A, Naganuma H, Nishimura K, Tachikawa M, Hosoya K, Terasaki T (2004) Brain insulin impairs amyloid-beta (1-40) clearance from the brain. J Neurosci 24:9632-9637. CrossRef Medline

Sims-Robinson C, Kim B, Rosko A, Feldman EL (2010) How does diabetes accelerate Alzheimer disease pathology? Nat Rev Neurol 6:551-559. CrossRef Medline 
Sperling RA, Aisen PS, Beckett LA, Bennett DA, Craft S, Fagan AM, Iwatsubo T, Jack CR Jr, Kaye J, Montine TJ, Park DC, Reiman EM, Rowe CC, Siemers E, Stern Y, Yaffe K, Carrillo MC, Thies B, Morrison-Bogorad M, Wagster MV, et al. (2011) Toward defining the preclinical stages of Alzheimer's disease: recommendations from the National Institute on Aging-Alzheimer's Association workgroups on diagnostic guidelines for Alzheimer's disease. Alzheimers Dement 7:280-292. CrossRef Medline

Stanley M, Macauley SL, Holtzman DM (2016) Changes in insulin and insulin signaling in Alzheimer's disease: cause or consequence? J Exp Med 213:1375-1385. CrossRef Medline

Stein LJ, Dorsa DM, Baskin DG, Figlewicz DP, Porte D Jr, Woods SC (1987) Reduced effect of experimental peripheral hyperinsulinemia to elevate cerebrospinal fluid insulin concentrations of obese Zucker rats. Endocrinology 121:1611-1615. CrossRef Medline

Stöhr O, Schilbach K, Moll L, Hettich MM, Freude S, Wunderlich FT, Ernst M, Zemva J, Brüning JC, Krone W, Udelhoven M, Schubert M (2013) Insulin receptor signaling mediates APP processing and beta-amyloid accumulation without altering survival in a transgenic mouse model of Alzheimer's disease. Age 35:83-101. CrossRef Medline

Talbot K, Wang HY, Kazi H, Han LY, Bakshi KP, Stucky A, Fuino RL, Kawaguchi KR, Samoyedny AJ, Wilson RS, Arvanitakis Z, Schneider JA, Wolf BA, Bennett DA, Trojanowski JQ, Arnold SE (2012) Demonstrated brain insulin resistance in Alzheimer's disease patients is associated with IGF-1 resistance, IRS-1 dysregulation, and cognitive decline. J Clin Invest 122:1316-1338. CrossRef Medline

Wadman M (2012) US government sets out Alzheimer's plan. Nature 485: 426-427. CrossRef Medline

Watson GS, Peskind ER, Asthana S, Purganan K, Wait C, Chapman D, Schwartz MW, Plymate S, Craft S (2003) Insulin increases CSF Abeta42 levels in normal older adults. Neurology 60:1899-1903. CrossRef Medline

Weiland M, Bahr F, Höhne M, Schürmann A, Ziehm D, Joost HG (1991) The signaling potential of the receptors for insulin and insulin-like growth factor I (IGF-I) in 3T3-L1 adipocytes: comparison of glucose transport activity, induction of oncogene c-fos, glucose transporter mRNA, and DNA-synthesis. J Cell Physiol 149:428-435. CrossRef Medline

Willette AA, Johnson SC, Birdsill AC, Sager MA, Christian B, Baker LD, Craft S, Oh J, Statz E, Hermann BP, Jonaitis EM, Koscik RL, La Rue A, Asthana S, Bendlin BB (2015) Insulin resistance predicts brain amyloid deposition in late middle-aged adults. Alzheimers Dement 11:504-510. CrossRef Medline

Wojtaszewski JF, Hansen BF, Gade, Kiens B, Markuns JF, Goodyear LJ, Richter EA (2000) Insulin signaling and insulin sensitivity after exercise in human skeletal muscle. Diabetes 49:325-331. CrossRef Medline

Xie L, Kang H, Xu Q, Chen MJ, Liao Y, Thiyagarajan M, O’Donnell J, Christensen DJ, Nicholson C, Iliff JJ, Takano T, Deane R, Nedergaard M (2013) Sleep drives metabolite clearance from the adult brain. Science 342:373-377. CrossRef Medline

Yarchoan M, Toledo JB, Lee EB, Arvanitakis Z, Kazi H, Han LY, Louneva N, Lee VM, Kim SF, Trojanowski JQ, Arnold SE (2014) Abnormal serine phosphorylation of insulin receptor substrate 1 is associated with tau pathology in Alzheimer's disease and tauopathies. Acta Neuropathol 128: 679-689. CrossRef Medline

Zhao L, Teter B, Morihara T, Lim GP, Ambegaokar SS, Ubeda OJ, Frautschy SA, Cole GM (2004) Insulin-degrading enzyme as a downstream target of insulin receptor signaling cascade: implications for Alzheimer's disease intervention. J Neurosci 24:11120-11126. CrossRef Medline

Zhao WQ, De Felice FG, Fernandez S, Chen H, Lambert MP, Quon MJ, Krafft GA, Klein WL (2008) Amyloid beta oligomers induce impairment of neuronal insulin receptors. FASEB J 22:246-260. CrossRef Medline

Zuchero YJ, Chen X, Bien-Ly N, Bumbaca D, Tong RK, Gao X, Zhang S, Hoyte K, Luk W, Huntley MA, Phu L, Tan C, Kallop D, Weimer RM, Lu Y, Kirkpatrick DS, Ernst JA, Chih B, Dennis MS, Watts RJ (2016) Discovery of novel blood-brain barrier targets to enhance brain uptake of therapeutic antibodies. Neuron 89:70-82. CrossRef Medline 